\title{
APPLICATION OF THE ASSURE LEARNING MODEL IN IMPROVING THE LEARNING OUTCOMES OF CLASS IV ELEMENTARY SCHOOL STUDENTS
}

\author{
Nanda Saputra \\ STIT Al-Hilal Sigli \\ Nandasaputra680@gmail.com \\ Amiruddin \\ IAI Al-'Aziziyah Samalanga \\ amiruddinyes@gmail.com

\section{Miswar Saputra} \\ IAI Al-'Aziziyah Samalanga \\ miswaralfata@gmail.com
}

\begin{abstract}
The main problem in this study is the lack of student interest in learning and the low learning outcomes of Indonesian. The formulation of the problem in this study is whether the assure learning model can improve the learning outcomes of fourth grade students of SDN 2 Sigli ?. This study aims to determine the application of the assure learning model to improve learning outcomes of fifth grade students of SD Negeri 2 Sigli. This type of research is a classroom action research (PTK) which is carried out in two cycles. Each cycle consists of four stages, namely planning, implementing, observing, and reflecting. The research subjects were the fourth grade students of SDN 2 Sigli, totaling 22 students. Data collection techniques in this study were tests, observation, documentation and interviews. The results of this classroom action research indicate that the application of the assure learning model can improve student learning outcomes. This can be seen from the scores obtained by students in each cycle. In the first cycle, the students 'average score was 68.1, while in the second cycle, the students' average score was 75.
\end{abstract}

Keyword: assure learning model, learning outcomes, student

\begin{abstract}
Abstrak
Masalah utama dalam penelitian ini adalah kurangnya minat belajar siswa dan rendahnya hasil belajar bahasa Indonesia. Adapun rumusan masalah dalam penelitian ini adalah apakah model pembelajaran assure dapat meningkatkan hasil belajar siswa kelas IV SDN 2 Sigli?. Penelitian ini bertujuan untuk mengetahui penerapan model pembelajaran assure dapat meningkatkan hasil belajar siswa kelas V SD Negeri 2 Sigli. Jenis penelitian ini adalah penelitian tindakan kelas (PTK) yang dilaksanakan dalam dua siklus. Setiap siklus terdiri dari empat tahapan, yaitu perencanaan, pelaksanaan, observasi, dan refleksi. Subjek penelitian adalah peserta didik kelas IV SDN 2 Sigli yang berjumlah 22 peserta didik. Teknik pengumpulan data dalam penelitian ini adalah tes, observasi, dokumentasi dan wawancara. Hasil penelitian tindakan kelas ini menunjukkan bahwa penerapan model pembelajaran assure dapat meningkatkan hasil belajar siswa. Hal ini terlihat dari nilai yang diperoleh siswa pada masing-masing siklus. Pada siklus I mendapatkan nilai rata-rata siswa 68,1, sedangkan pada siklus II mendapatkan nilai rata-rata siswa 75.
\end{abstract}

Kata Kunci: model pembelajaran assure, hasil belajar, siswa

Program Studi Pendidikan Guru Madrasah Ibtidaiyah STAI Al-Azhar Menganti Gresik, Indonesia 
ZAHRA: Research And Tought Elmentary School Of Islam Journal Vol. (2) (2), (Agustus)(2021), (Halaman)(112-122)| 113

\section{Pendahuluan}

Pendidikan sangat penting dan diperlukan setiap orang untuk berpikir maju di era modern. Bangsa akan menjadi maju apabila pendidikan dapat terlaksana dengan baik. Setiap orang akan dapat mengungkapkan pemikiran dan mengembangkan bakat yang dimilikinya untuk memperoleh kehidupan yang lebih baik di masa mendatang. Selain itu pendidikan merupakan usaha yang sadar dan terencana untuk mewujudkan suasana belajar dan proses pembelajaran. Hal tersebut diperuntukkan agar peserta didik secara aktif dapat mengembangkan potensi dirinya untuk memiliki kekuatan seperti spiritual keagamaan, pengendalian diri/emosi, kepribadian, kecerdasan, akhlak mulia, serta keterampilan yang diperlukan dirinya dan masyarakat.

Sekolah Dasar merupakan tempat pengalaman pertama yang memberikan dasar pembentuk kepribadian individu. Sehubungan dengan hal itu guru perlu membekali siswanya dengan kepribadian, kemampuan, dan keterampilan dasar yang cukup sebagai landasan untuk mempersiapkan pengalamannya pada jenjang yang lebih tinggi. Pembelajaran di Sekolah Dasar dewasa ini kurang ditunjang dengan pembelajaran yang inovatif. Sehingga mengakibatkan materi yang disampaikan guru menjadi sukar diterima oleh peserta didik sehingga pada hasil evaluasi belajar juga tidak akan sesuai dengan apa yang diharapkan. Seperti kesulitan para peserta didik dalam menguasai dan memahami materi pada mata pelajaran tertentu, tidak adanya usaha dari peserta didik untuk mencari dan menemukan pemecahan masalah yang harus dihadapi, dan juga ketidakmampuan guru dalam melatih kemampuan peserta didik agar dapat lebih baik lagi dari sebelumnya.

Kecenderungan model pembelajaran selama ini adalah model pembelajaran langsung dimana guru menjadi titik pusat pembelajaran. Materi terkesan menjadi kurang menarik dan membosankan bagi peserta didik. Peserta didik belum bisa memaknai manfaat mempelajari materi karena belum dikenalkan sebelumnya tentang pentingnya mengetahui manfaat bagi kehidupan peserta didik. Hal ini juga berdampak pada hasil belajar model pembelajaran langsung cenderung rendah. Dari sekian banyak model pembelajaran yang ada, ada salah satu model yang dapat digunakan untuk meningkatkan pemahaman konsep peserta didik dalam memahami materi pelajaran yaitu dengan menerapkan model pembelajaran assure. Rahmawati (2015:83) mengungkapkan bahwa model assure merupakan panduan prosedural untuk merencanakan dan menyampaikan pelajaran yang menyertakan media. Model ini merupakan model yang menitikberatkan pada perencanaan yang struktural dimana satu langkah akan mempengaruhi langkah berikutnya. 
ZAHRA: Research And Tought Elmentary School Of Islam Journal Vol. (2) (2), (Agustus)(2021), (Halaman)(112-122)| 114

Model pembelajaran ini lebih berorientasi kepada pemanfaatan media dan teknologi dalam menciptakan proses dan aktivitas pembelajaran yang diinginkan (Pribadi, 2011:29). Model ini juga dapat disesuaikan sesuai tujuan, jadi dengan model pembelajaran ini guru dapat membuat suatu rancangan pembelajaran yang memusatkan pada tujuan pemahaman konsep suatu materi. Selain itu dengan pembelajaran yang bertumpu pada model pembelajaran assure ini konsep-konsep dalam materi akan lebih mudah diwujudkan atau direalisasikan melalui gambar atau contoh. Model pembelajaran assure ini adalah suatu model dimana setiap langkah-langkahnya dilakukan bertahap dan menyeluruh agar dapat memberikan hasil yang optimal. Selain itu model pembelajaran assure dapat diaplikasikan untuk mendesain aktivitas belajar baik secara kelompok maupun individu. Inti dari pengaplikasian model pembelajaran assure ini adalah pemanfaatan media dan teknologi komputer dalam pembelajaran. Sehingga dengan adanya pemanfaatan media akan membuat peserta didik merasakan pengalaman belajar yang baru.

Berdasarkan uraian di atas, maka penerapan model pembelajaran assure menjadi salah satu alternatif yang efektif sebagai upaya untuk meningkatkan hasil belajar siswa kelas IV SDN 2 Sigli. Dari uraian latar belakang di atas, maka rumusan masalah dalam penelitian ini apakah penerapan model pembelajaran assure dapat meningkatkan hasil belajar siswa kelas IV SDN 2 Sigli?. Adapun tujuan penelitian ini adalah untuk menerapkan model pembelajaran assure dalam meningkatkan hasil belajar siswa kelas IV SD Negeri 2 Sigli.

\section{Pengertian Model Pembelajaran Assure}

Menurut Kamus Besar Bahasa Indonesia (2008:923) model berarti pola (contoh, acuan, ragam). Menurut Suprijono (2012:45-46) model diartikan sebagai bentuk representasi akurat sebagai proses aktual yang memungkinkan seseorang atau sekelompok orang mencoba bertindak berdasarkan model itu. Model pembelajaran adalah suatu perencanaan atau suatu pola yang digunakan sebagai pedoman dalam tutorial dan untuk menetukan perangkat perangkat pembelajaran termasuk didalamnya buku-buku, film, komputer, kurikulum, dan lain-lain (Trianto 2011:5). Istilah assure diperkenalkan oleh Sharon E. Smaldino, Deborah L. Lowther, dan James D. Russell dalam buku "Instructional Technology and Media for Learning”. ASSURE merupakan nama singkatan dari langkah-langkah model pembelajaran yang terdiri dari enam komponen yaitu: Analyze learners characteristics (analisis karakteristik siswa); State objectives (menetapkan tujuan); Select methods, media and materials (memilih metode, media dan bahan ajar); Utilize methods, media and materials (memanfaatkan metode, media dan bahan ajar); Requires learner participation (mendorong partisipasi siswa); Evaluation and revision (evaluasi dan revisi) (Pribadi 2011:29). 
ZAHRA: Research And Tought Elmentary School Of Islam Journal Vol. (2) (2), (Agustus)(2021), (Halaman)(112-122)| 115

Setiawibawa (2012:2) mengungkapkan bahwa model pembelajaran assure dapat digunakan untuk menetapkan pengalaman belajar yang dapat membantu siswa dalam mencapai kompetensi yang diinginkan. Langkah awal dari model assure ini adalah mengenal siswa sebagai individu yang akan menempuh program pembelajaran, dengan mengenal dan mengetahui "profil" siswa yang akan menempuh proses belajar, guru, instruktur, pelatih dan perancang program pembelajaran dapat menentukan kompetensi yang sesuai dan perlu dicapai. Assure dikembangkan agar dapat digunakan oleh guru, instruktur, dan pelatih dalam kegiatan pembelajaran khususnya yang memanfaatkan media dan teknologi didalamnya. Model pembelajaran ini dengan kata lain dapat digunakan untuk memfasilitasi proses belajar siswa agar mampu mencapai kompetensi seperti yang diinginkan (Likhah 2012: 4)

Model pembelajaran ini merupakan model yang bersifat prosedural yang dibangun untuk menciptakan program pembelajaran yang efektif, efisien, dan menarik. Dalam model ini pemanfaatan media dan teknologi menjadi suatu keharusan karena digunakan untuk membantu siswa dalam mencapai tujuan pembelajaran. Pemanfaatan media yang sejalan dengan metode pembelajaran akan mampu melibatkan siswa secara intensif dalam aktivitas pembelajaran (Pribadi, 2011:30)

Rachmawati (2015:7) berpendapat bahwa model pembelajaran ini adalah model yang paling sederhana untuk pembelajaran. Model yang didasarkan pada pemanfaatan teknologi dan media, serta dikembangkan melalui pemilihan dan pemanfaatan metode, materi ajar dan peran siswa dalam proses pembelajaran. Achmadi dkk. (2014:37) mengatakan bahwa model assure ini merupakan rujukan bagi pendidik dalam membelajarkan peserta didik dalam pembelajaran yang direncanakan dan disusun secara sistematis dengan mengintegrasikan teknologi dan media.

Dari beberapa definisi tentang model pembelajaran assure dapat disimpulkan bahwa model pembelajaran assure adalah model pembelajaran yang berorientasi pada pemilihan dan pemanfaatan media, metode, dan bahan ajar yang dapat memfasilitasi siswa dalam menempuh aktivitas pembelajaran. Model assure sesuai dengan namanya, jika di implementasikan dengan baik diharapkan dapat menjamin terciptanya aktivitas pembelajaran yang dapat memfasilitasi siswa untuk mencapai kompetensi yang diinginkan.

\section{Hasil Belajar}

Hasil belajar adalah penguasaan pengetahuan atau keterampilan yang dikembangkan oleh mata pelajaran, lazimnya ditunjukkan dengan nilai tes atau angka yang diberikan guru (tim penyusun KBBI, 2005). Oemar Mamalk (2003) mengatakan bahwa hasil belajar adalah bila seseorang telah belajar akan terjadi perubahan tingkah laku pada orang tersebut. 
ZAHRA: Research And Tought Elmentary School Of Islam Journal Vol. (2) (2), (Agustus)(2021), (Halaman)(112-122)| 116 Berkaitan dengan hasil belajar W.S Winkel (2009) berpendapat bahwa hasil belajar adalah perubahan tingkah laku. Gagne mengemukakan ada lima kategori tipe hasil belajar, yakni verbal information, intelektual skill, cognitive strategy, attitude dan motor skill (Nana Sudjana, 2000). Berdasarkan uraian pengertian hasil belajar, maka dapat disimpulkan bahwa bahwa hasil belajar merupakan pencapaian perubahan perilaku baik dari segi kognitif, afektif dan psikomotorik dari proses belajar yang dihasilkan dari latihan dan pengalaman belajar. Untuk memperoleh hasil belajar diperlukan evaluasi penilaian sebagai tindak lanjut untuk mengukur tingkat penguasaan siswa setelah mengikuti proses pembelajaran.

Susianha (2009) menjelaskan bahwa hasil belajar dipengaruhi oleh dua faktor yaitu faktor dari diri siswa cian faktor dari lingkungan. Faktor dari dirt slswa adalah kemampuan yang dimilikinya, motivasi belajar, minat dan perhatian, sikap dan kebiasaan belajar, ketekunan, sosial ekonomi, faktor fisik dan psikis. Faktor ini berpengaruh besar terhadap pencapaian hasil belajar siswa yakni sebesar 70\% sedangkan yang 30\% dipengaruhi oleh lingkungannya. Hasil belajar dapat dilihat darl nilai ulangan harian (formatif) dan tes semester (sumatif). Dalam penelitian ini, yang dimaksud adalah hasil tes setelah pembelajaran dengan menggunakan model pembelajaran assure.

\section{Bahasa Indonesia}

Bahasa Indonesia adalah alat komunikasi yang dipergunakan oleh masyarakat Indonesia untuk keperluan sehari-hari,misalnya belajar,bekerja sama,dan berinteraksi. Bahasa Indonesia merupakan bahasa nasional dan bahasa resmi di Indonesia. Bahasa nasional adalah bahasa yang menjadi standar di Negara Indonesia. Sebagai bahasa nasional, bahasa Indonesia tidak mengikat pemakainya untuk sesuai dengan kaidah dasar. Bahasa Indonesia digunakan secara non resmi, santai dan bebas. Dalam pergaulan sehari-hari antar warga yang dipentingkan adalah makna yang disampaikan. Pemakai bahasa Indonesia dalam konteks bahasa nasional dapat menggunakan dengan bebas menggunakan ujarannya baik lisan maupun tulis.

Suwarna (2002:4) bahasa merupakan alat utama untuk berkomunikasi dalam kehidupan manusia, baik secara individu maupun kolektif sosial. Aminuddin (2005:28-29) mengartikan bahasa sebagai suatu sistem lambang arbitrer yang menggunakan suatu masyarakat untuk bekerja sama, berinteraksi, dan mengidentifikasikan diri. Chaer dan Agustina (1995:14) fungsi utama bahasa adalah sebagai alat komunikasi. Hal ini sejalan dengan Soeparno (1993:5) yang menyatakan bahwa fungsi umum bahasa adalah sebagai alat komunikasi sosial. Sosiolinguistik memandang bahasa sebagai tingkah laku sosial (sosial behavior) yang dipakai dalam komunikasi sosial. 
ZAHRA: Research And Tought Elmentary School Of Islam Journal Vol. (2) (2), (Agustus)(2021), (Halaman)(112-122)| 117

Belajar bahasa Indonesia merupakan salah satu sarana yang dapat mengakses berbagai informasi dan kemajuan ilmu pengetahuan. Untuk itu, kemahiran berkomunikasi dalam bahasa Indonesia secara lisan dan tertulis harus benarbenar dimiliki dan ditingkatkan dalam pembelajaran. Berdasarkan hal tersebut, posisi bahasa Indonesia perlu mendapat perhatian khusus terutama bagi pembelajar bahasa Indonesia. Hal ini terutama bagi pembelajar bahasa Indonesia yang masih awal dalam penguasaan kaidah bahasa Indonesia. Selain itu, bahasa Indonesia digunakan sebagai sarana komunikasi, buku-buku pengetahuan, suratkabar, iklan, persuratan, percakapan sehari-hari, radio, televisi, pidato dan sebagainya menggunakan bahasa Indonesia.

\section{Metode Penelitian}

Rancangan penelitian yang digunakan adalah penelitian tindakan kelas (PTK). PTK ini memiliki tujuan untuk memperbaiki atau meningkatkan mutu (kualitas) pembelajaran di kelas melalui suatu tindakan tertentu dalam satu atau beberapa siklus sesuai yang dibutuhkan. Adapun tahap-tahap penelitian ini menurut Arikunto (2010:131) adalah (1) perencanaan; (2) pelaksanaan dan pengamatan; (3) refleksi. Subjek penelitian ini adalah guru dan siswa kelas IV SDN 2 Sigli yang berjumlah 22 siswa yang terdiri dari 10 siswa laki-laki dan 12 siswa perempuan. Lokasi penelitian ini adalah SDN 2 Sigli. Teknik pengumpulan data dalam penelitian ini dilakukan dengan: (1) observasi; (2) tes; (3) catatan lapangan. Teknik tersebut digunakan untuk mendeskripsikan pelaksanaan pembelajaran, hasil belajar bahasa Indonesia, mendeskripsikan kendala-kendala selama menerapkan model pembelajaran dan cara mengatasinya.

Instrumen penilaian yang digunakan adalah: (1) lembar pelaksanaan pembelajaran; (2) lembar tes hasil belajar siswa; (3) lembar catatan lapangan. Lembar pelaksanaan pembelajaran digunakan untuk memperoleh data tentang pelaksaanan pembelajaran dan ketercapaian. Lembar tes hasil belajar siswa digunakan untuk memperoleh data tentang hasil belajar siswa. Catatan lapangan dilakukan untuk mencatat kendala-kendala yang terjadi pada waktu berlangsungnya pembelajaran. Selanjutnya data yang diperoleh akan diolah dan dianalisis secara kualitatif dan kuantitatif.

Data pelaksanaan pembelajaran dianalisis secara kuantitatif menggunakan rumus:

$$
P=\frac{F}{N} \times 100 \%
$$

\section{Keterangan:}

$\mathrm{P}=$ Angka persentase

$\mathrm{F}=$ Frekuensi yang sedang dicari persentasenya

$\mathrm{N}$ = Jumlah frekuensi/ banyak individu

Untuk menghitung nilai rata-rata (mean) dalam penelitian ini, maka penulis menggunakan rumus sebagai berikut: 
ZAHRA: Research And Tought Elmentary School Of Islam Journal Vol. (2) (2), (Agustus)(2021), (Halaman)(112-122)| 118 $\bar{X}=\frac{\sum x}{N}$

Keterangan :

$\bar{X} \quad=$ Rata-Rata (Mean)

$\sum x=$ Jumlah seluruh skor

$\mathrm{N} \quad=$ Jumlah Individu (Sudjana, 2009:109)

Setiap siswa dikatakan tuntas belajarnya (ketuntasan individu) jika proposi jawaban benar siswa $\geq 65$, dan suatu kelas dikatakan tuntas belajarnya (ketuntasan klasikal) jika di dalam kelas tersebut terdapat $\geq 85 \%$ siswa yang tuntas belajarnya. Dan nilai KKM pada SDN 2 Sigli adalah 70 .

\section{Hasil Penelitian}

\section{Tindakan Pembelajaran Siklus I}

Adapun perolehan hasil evaluasi pada Siklus I dapat dilihat pada tabel berikut:

Tabel. 4.1 Perolehan Nilai Hasil Evaluasi pada Siklus I

\begin{tabular}{|c|c|c|c|}
\hline No. & Nama Siswa & Nilai Evaluasi & Keterangan \\
\hline 1 & ML & 60 & Tidak Tuntas \\
\hline 2 & SU & 70 & Tuntas \\
\hline 3 & NT & 50 & Tidak Tuntas \\
\hline 4 & VF & 100 & Tuntas \\
\hline 5 & $\mathrm{~N}$ & 90 & Tuntas \\
\hline 6 & FF & 65 & Tuntas \\
\hline 7 & SA & 70 & Tuntas \\
\hline 8 & $\mathrm{MZ}$ & 70 & Tuntas \\
\hline 9 & MA & 50 & Tidak Tuntas \\
\hline 10 & MR & 65 & Tuntas \\
\hline 11 & IS & 50 & Tidak Tuntas \\
\hline 12 & A & 75 & Tuntas \\
\hline 13 & $\mathrm{RF}$ & 60 & Tidak Tuntas \\
\hline 14 & FA & 25 & Tidak Tuntas \\
\hline 15 & $\mathrm{~N}$ & 70 & Tuntas \\
\hline 16 & RR & 65 & Tuntas \\
\hline 17 & $\mathrm{UZ}$ & 100 & Tuntas \\
\hline 18 & $\mathrm{~N}$ & 70 & Tuntas \\
\hline 19 & $\mathrm{~J}$ & 75 & Tuntas \\
\hline 20 & $\mathrm{~N}$ & 75 & Tuntas \\
\hline 21 & NA & 75 & Tuntas \\
\hline
\end{tabular}


ZAHRA: Research And Tought Elmentary School Of Islam Journal Vol. (2) (2), (Agustus)(2021), (Halaman)(112-122)| 119

\begin{tabular}{llcc}
\hline 22 & AA & 70 & Tuntas \\
\hline \multirow{2}{*}{ Jumlah } & 1500 & \\
\cline { 2 - 4 } & Nilai rata-rata & $\mathbf{6 8 , 1}$
\end{tabular}

Berdasarkan hasil yang terlihat pada tabel 4.1, maka perolehan nilai terendah 25 dan nilai tertinggi 100 dengan rincian yang memperoleh nilai 25 sebanyak 1 orang. Selanjutnya, yang memperoleh nilai 50 sebanyak 3 orang, nilai 60 sebanyak 2 orang, nilai 65 sebanyak 3 orang, nilai 70 sebanyak 5 orang, nilai 75 sebanyak 4 orang, dan nilai 90 sebanyak 1 orang, dan nilai 100 sebanyak 2 orang, sehingga nilai rata-rata yang diperoleh secara klasikal adalah 68,1 . Adapun kategori nilai yang diperoleh masing-masing siswa dapat dilihat dari tercapainya siswa dengan nilai kriteria ketuntasan secara minimal dan ketuntasan secara klasikal yang penulis tabulasikan dalam tabel berikut ini:

Tabel 4.2 Kriteria Nilai yang dicapai Siswa Siklus I

\begin{tabular}{ccccc}
\hline Siklus & Nilai & F & $\%$ & Keterangan \\
\hline \multirow{2}{*}{ I } & $\geq 65$ & 16 & 73 & Tuntas \\
& $<65$ & 6 & 27 & Tidak Tuntas \\
\hline Jumlah & & 22 & $100 \%$ &
\end{tabular}

Berdasarkan tabel di atas dapat dijelaskan bahwa sejumlah siswa yang telah mencapai ketuntasan yaitu 16 orang dengan persentase $73 \%$. Sedangkan siswa yang masih di bawah nilai kriteria ketuntasan minimal yaitu berjumlah 6 orang dengan persentase 27\%. Hal ini menunjukkan bahwa belum tercapainya ketuntasan minimal dan ketuntasan secara klasikal. Oleh karena itu, peneliti akan melakukan tindak lanjut dengan melaksanakan proses pembelajaran pada siklus ke II.

\section{Tindakan Pembelajaran Siklus II}

Tabel 4.3 Perolehan Hasil Kerja Kelompok pada Siklus II

\begin{tabular}{|c|c|c|c|c|c|}
\hline & Nama Kelompok & & Nilai & Nilai & \\
\hline No. & & Kode Siswa & Kelompok & Individu & Keterangan \\
\hline \multirow{4}{*}{1} & \multirow{4}{*}{ A } & ML & \multirow{4}{*}{90} & 75 & Tuntas \\
\hline & & SU & & 75 & Tuntas \\
\hline & & NT & & 80 & Tuntas \\
\hline & & VR & & 70 & Tuntas \\
\hline \multirow{8}{*}{2} & \multirow{7}{*}{ B } & FF & \multirow{8}{*}{90} & 75 & Tuntas \\
\hline & & SA & & 75 & Tuntas \\
\hline & & $\mathrm{MZ}$ & & 75 & Tuntas \\
\hline & & $\mathrm{MZ}$ & & 70 & Tuntas \\
\hline & & AA & & 70 & Tuntas \\
\hline & & $\mathrm{F}$ & & 75 & Tuntas \\
\hline & & MR & & 85 & Tuntas \\
\hline & & IS & & 60 & Tidak Tuntas \\
\hline
\end{tabular}




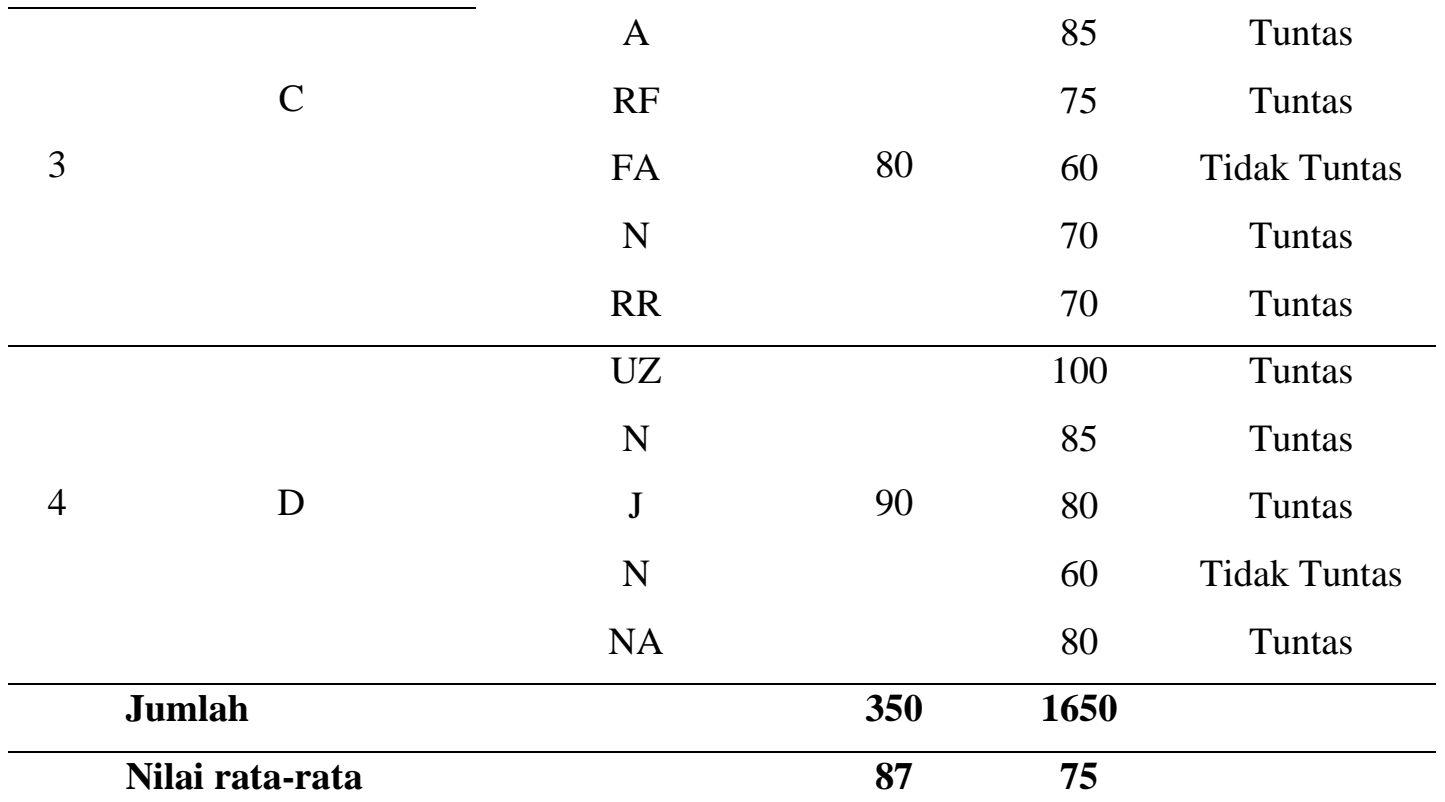

Berdasarkan hasil yang terlihat pada tabel 4.3, maka perolehan nilai hasil kerja kelompok pada siklus II, yakni kelompok A memperoleh nilai 90, kelompok B memperoleh nilai 90, kelompok C memperoleh nilai 80, dan kelompok D memperoleh nilai 90. Hasil pengamatan aktivitas siswa pada siklus II, menunjukkan bahwa kemampuan hasil belajar siswa dalam menguasai materi membaca intensif mengalami peningkatan. Hal itu terlihat dari hasil yang diperoleh siswa pada siklus II hanya 3 orang siswa yang memperoleh nilai dibawah kriteria ketuntasan minimal dan ketuntasan klasikal yang penulis tabulasikan pada tabel berikut ini:

Tabel 4.4 Kriteria Nilai yang dicapai Siswa Siklus II

\begin{tabular}{ccccc}
\hline Siklus & Nilai & F & $\%$ & Keterangan \\
\hline \multirow{2}{*}{ II } & $\geq 65$ & 19 & 87 & Tuntas \\
Total & $<65$ & 3 & 13 & Tidak Tuntas \\
\hline
\end{tabular}

Dari analisis terhadap hasil belajar yang dicapai oleh siswa diperoleh data bahwa siswa yang memperoleh nilai di atas KKM 65 jumlah berjumlah 22 orang siswa dari keseluruhan jumlah siswa 22 orang, maka jumlah siswa yang tuntas adalah sebesar $87 \%$, jumlah siswa yang belum tuntas atau memperoleh nilai di bawah KKM 65 adalah 3 orang dengan persentase 13\%. Hal ini menunjukkan bahwa sudah tercapainya kriteria ketuntasan minimal dan kriteria ketuntasan secara klasikal. Maka, peningkatan hasil belajar melalui penarapan model pembelajaran assure pada siswa kelas IV SDN 2 Sigli telah mencapai ketuntasan yang maksimal pada siklus II.

\section{Diskusi}

\section{Siklus I}

Penelitian tindakan kelas (PTK) pada siklus I yaitu pada materi "membaca intensif". Pembelajaran dilaksanakan dengan menggunakan model konvensional pendekatan ceramah dan tanya jawab dengan jumlah siswa 22 orang yang terdiri dari 10 siswa laki-laki dan 12 siswa perempuan. Pada siklus I yaitu materi "membaca intensif", kebanyakan siswa sudah mengerti dan sudah bisa 
ZAHRA: Research And Tought Elmentary School Of Islam Journal Vol. (2) (2), (Agustus)(2021), (Halaman)(112-122)| 121 memberikan contohnya, tetapi masih ada juga siswa yang belum paham tentang membaca intensif yaitu sebanyak 6 orang siswa.

Pada siklus I yang tuntas dalam pembelajaran atas sebanyak 16 orang siswa yang presentasinya 73\%. Oleh sebab itu, perlu melanjutkan pada siklus berikutnya karena pada siklus I belum mencapai kriteria ketuntasan klasikal sesuai yang ditargetkan yaitu mencapai $85 \%$. Pada siklus I pembelajaran masih kurang aktif, belum semua siswa terlibat aktif. Sehingga peneliti dapat menyimpulkan bahwa proses peneliti tindakan kelas yang telah dilaksanakan pada siklus I belum berhasil karena masih ada sebagian siswa yang memperoleh nilai di bawah kriteria ketuntasan minimal (KKM). Hal ini menunjukkan perlu adanya penelitian tindakan selanjutnya sebagai tindakan untuk memperbaiki proses pembelajaran yang telah dilaksanakan.

Menurut pengamatan observer, aktivitas siswa yang sudah baik pada siklus I yaitu mendengarkan instruksi dari guru cara mengerjakan LKS dan siswa antusias mengerjakan LKS, siswa mencatat materi yang diberikan guru dan di akhir pembelajaran siswa mendengarkan pesan moral dari guru. Adapun aktivitas siswa yang masih kurang baik pada siklus I, menurut pengamatan observer yaitu hanya sebagian siswa yang termotivasi mengikuti pembelajaran, sebagian siswa merasa bosan karena penyajian pembelajaran hanya menggunakan pendekatan ceramah dan tanya jawab, hanya sebagian siswa yang berani bertanya dan menanggapi pertanyaan dari peneliti, intinya hanya sebagian siswa yang terlibat aktif dalam pembelajaran.

Pada siklus I nilai rata-rata yang diperoleh siswa 68,1 sehingga dapat disimpulkan pembelajaran siklus I kurang berhasil dan belum tuntas, akan tetapi kekurangan pada proses pembelajaran siklus I harus diperbaiki pada tindakan selanjutnya yang dilakukan pada siklus II, peneliti perlu menyiapkan rencana pembelajaran yang lebih bermakna.

\section{Siklus II}

Pada pembelajaran siklus II materi yang disajikan tetap sama yaitu membaca intensif model pembelajaran yang berbeda dengan menggunakan model pembelajaran assure, pada siklus II siswa sudah dibentuk dalam beberapa kelompok dan peneliti juga sudah menyediakan media pembelajaran agar pembelajaran lebih aktif dan menyenangkan. Berdasarkan data pada tabel 4.3 hasil belajar yang diperoleh siswa mengalami peningkatan secara maksimal dengan kriteria ketuntasan secara klasikal yang ditargetkan peneliti yaitu $87 \%$ yaitu mencapai 19 siswa melebihi nilai ketuntasan secara klasikal yang ditargetkan $85 \%$. Maka proses pembelajaran dengan penelitian tindakan kelas (PTK) dihentikan pada siklus II karena telah mencapai nilai ketuntasan maksimal.

Menurut pengamatan observer, aktivitas siswa pada siklus II yaitu siswa sangat antusias dalam bertanya dan menanggapi pertanyaan dari peneliti, siswa sangat aktif dalam pembelajaran karena model pembelajaran yang menyenangkan, adanya model talking stick yang dapat diamati langsung oleh siswa. Pada siklus II nilai rata-rata siswa diperoleh 75, maka dapat disimpulkan pembelajaran bahasa Indonesia pada materi membaca intensif sudah tuntas dibandingkan nilai yang diperoleh siswa pada siklus I, akan tetapi kekurangan pada siklus I bisa diperbaiki pada siklus II. Cara melakukan 
ZAHRA: Research And Tought Elmentary School Of Islam Journal Vol. (2) (2), (Agustus)(2021), (Halaman)(112-122)| 122 perbaikan pada siklus II, peneliti melakukan berbagai upaya yaitu menggunakan media lingkungan, meminta beberapa siswa mendemonstrasikan membaca intensif.

\section{Simpulan}

Penerapan model assure pada kelas IV SDN 2 Sigli dapat meningkatkan hasil belajar siswa dalam pembelajaran bahasa indonesia, khususnya pada materi membaca intensif. Hal ini terlihat dari nilai yang diperoleh siswa pada masing-masing siklus. Pada siklus I mendapatkan nilai rata-rata siswa 68,1 , sedangkan pada siklus II mendapatkan nilai rata-rata siswa 75 . Aktifitas siswa lebih aktif dalam belajar dengan penerapan model assure pada pembelajaran bahasa Indonesia pada materi membaca intensif di kelas IV SDN 2 Sigli dengan adanya kerjasama antar siswa dalam memecahkan permasalahan yang dihadapi.

\section{Daftar Pustaka}

Aminuddin. (2005). Semantik: Pengantar Studi Tentang Makna. Bandung: Sinar Baru.

Arikunto, S. (2010). Prosedur Penelitian Suatu Pendekatan Praktik. Jakarta: Rineka Cipta.

Achmadi, Heri.dkk. (2013). Penerapan Model ASSURE Dengan Menggunakan Media Power Point Dalam Pembelajaran Bahasa Inggris Sebagai Usaha Peningkatan Motivasi Dan Prestasi Belajar Siswa Kelas X MAN Sukoharjo Tahun Pelajaran 2012/2013. Jurnal Tekonologi Pendidikan dan Pembelajaran. Vol.2, No.1.

Chaer, Abdul dan Leoni Agustina. (1995). Sosiolinguistik: Suatu Pengantar. Jakarta: Rineka Cipta.

Moeliono dkk. (2008). Kamus Besar Bahasa Indonesia Pusat Bahasa. Jakarta: Gramedia Pustaka Utama.

Pribadi, Benny A. (2011). Model Assure untuk Mendesain Pembelajaran Sukses. Jakarta: Dian Rakyat.

Rachmawati, Fadhilah. (2015). Efektifitas Model Pembelajaran Assure Dengan Pendekatan Scientific Dalam Meningkatkan Hasil Belajar Materi Pokok Pengukuran Kelas 3 Semester Gasal Di MI Asas Islam Kalibening Salatiga. Semarang: Universitas Islam Negeri Walisongo. http://eprints.Walisongo.ac.id/ 4599/ diakses tanggal 2 Desember 2020.

Soeparno. (1993). Dasar-dasar Linguistik. Yogyakarta: Mitra Gama Widya.

Sudjana, Nana. (2009). Dasar-Dasar Proses Belajar Mengajar. Bandung: PT. Sinar Baru Alpesindo.

Sudjana, N. (2009). Penilaian Hasil Proses Belajar Mengajar. Bandung: Remaja Rosda Karya.

Suprijono, Agus. (2012). Cooperative Learning. Surabaya: Pustaka Belajar.

Susianha. (2009). Pembelajaran aktif dengan prakfikum. http://susianha.bIogspot.com. Diakses tanggal 02 Desember 2020.

Suwarna. (2002). Strategi Penguasaan Berbahasa. Yogyakarta: Adicita Karya Nusa.

Trianto. (2011). Model-model Pembelajaran Inovatif. Jakarta: Prestasi Pustaka

Winkel, W.S. (1999). Psikologi Pendidikan dan Evaluasi Belajar. Jakarta: Gramedia. 